\title{
Efficiency of playback for assessing the occurrence of five bird species in Brazilian Atlantic Forest fragments
}

\author{
DANILO BOSCOLO ${ }^{1}$, JEAN PAUL METZGER ${ }^{1}$ and JACQUES M.E. VIELLIARD ${ }^{2}$ \\ ${ }^{1}$ Departamento de Ecologia, Instituto de Biociências, Universidade de São Paulo \\ Rua do Matão, 321, Travessa 14, 05508-900 São Paulo, SP, Brasil \\ 2 Departmento de Zoologia, Instituto de Biologia, Universidade Estatual de Campinas \\ Caixa Postal 6109, 13083-970 Campinas, SP, Brasil \\ Manuscript received on April 17, 2006; accepted for publication on April 19, 2006; \\ contributed by JACQUES M.E. VIELLIARD*
}

\begin{abstract}
Playback of bird songs is a useful technique for species detection; however, this method is usually not standardized. We tested playback efficiency for five Atlantic Forest birds (White-browed Warbler Basileuterus leucoblepharus, Giant Antshrike Batara cinerea, Swallow-tailed Manakin Chiroxiphia caudata, Whiteshouldered Fire-eye Pyriglena leucoptera and Surucua Trogon Trogon surrucura) for different time of the day, season of the year and species abundance at the Morro Grande Forest Reserve (South-eastern Brazil) and at thirteen forest fragments in a nearby landscape. Vocalizations were broadcasted monthly at sunrise, noon and sunset, during one year. For B. leucoblepharus, C. caudata and T. surrucura, sunrise and noon were more efficient than sunset. Batara cinerea presented higher efficiency from July to October. Playback expanded the favourable period for avifaunal surveys in tropical forest, usually restricted to early morning in the breeding season. The playback was efficient in detecting the presence of all species when the abundance was not too low. But only B. leucoblepharus and T. surrucura showed abundance values significantly related to this efficiency. The present study provided a precise indication of the best daily and seasonal periods and a confidence interval to maximize the efficiency of playback to detect the occurrence of these forest species.
\end{abstract}

Key words: playback, birds, forest fragments, methodology development, Atlantic forest, São Paulo State.

\section{INTRODUCTION}

Species occurrence data have often been used to monitor populations in fragmented habitats and to understand the effects of fragmentation on population survival (Hanski 1994, Clergeau and Burel 1997, Lindenmayer et al. 1999). This kind of data should be easy to collect, enabling surveys of a large number of habitat fragments in a short period of time. To be efficient, these methods must be fast in

*Member Academia Brasileira de Ciências Correspondence to: Jean Paul Metzger

E-mail: jpm@ib.usp.br the detection of the species presence and accurate in the recognition of their absence.

One main challenge is to avoid the problem of "false absence" (Thompson 2002). Cryptic behaviour or seasonal and daily variations in species activity can make this task difficult, especially if the survey is conducted inside dense habitats such as neotropical forests (Catchpole and Slater 1995, Sick 1997), where visual contact is seriously limited. To reduce this problem, surveys may be conducted with the assistance of playback calling.

Many studies have revealed that the use of play- 
back increases the number of contacts during bird surveys (Johnson et al. 1981, Rosenfield et al. 1985, Johnson and Dinsmore 1986, Kaufmann 1988, Swift et al. 1988, Sliwa and Sherry 1992). Some experiments indicated that the playback of conspecific songs is efficient in inducing aggressive responses from various bird species, allowing their detection (Milligan 1966, Møller 1992, Catchpole and Slater 1995). Mosher et al. (1990) pointed out that the use of playback during bird surveys might not only increase the contact rate but also reduce the interval needed for the first contact. Other studies, however, pointed out that variations in the abundance of birds in the forest might have an effect on the results obtained by playback experiments (Glahn 1974, Mosher and Fuller 1996, Schieck 1997). Although playback techniques are widely used to survey birds, few studies have been conducted with the aim of standardizing it. According to Morrell et al. (1991) and Ratcliffe et al. (1998), the standardization of the technique can reduce the operation cost and increase the possibility of collecting a large data set in a short time. These factors become even more important when the objective is to sample a large number of fragments.

The current study was designed to develop an accurate and simple tool to detect the presence and absence (occurrence pattern) of strictly forest bird species inside a tropical fragmented landscape. Our specific objectives were: i) to verify the time of the day and season of the year when some Atlantic Forest bird species are more efficiently detected by playback; ii) to test if the efficiency of the technique is affected by the abundance of the birds.

\section{MATERIALS AND METHODS}

\section{STUDY REGION}

The study region was located on the Atlantic Plateau of São Paulo (Brazil), between the municipal districts of Cotia and Ibiúna $\left(23^{\circ} 35^{\prime}-23^{\circ} 50^{\prime} \mathrm{S}\right.$ and $\left.46^{\circ} 45^{\prime}-47^{\circ} 15^{\prime} \mathrm{W}\right)$. Local relief is characterized by hills with more than $15 \%$ of inclination and elevations between 850 and $1100 \mathrm{~m}$ (Ross and Moroz
1997). The climate type is temperate and rainy, as Köppen's (1948) Cfa. Mean monthly temperature ranges from $11^{\circ} \mathrm{C}$ to $27^{\circ} \mathrm{C}$ and mean annual precipitation is about $1400 \mathrm{~mm}$, with the coldest and driest months between April and August. The original vegetation cover was classified as "dense montane ombrophilous Atlantic Forest" (Veloso et al. 1991). Nowadays, the region is composed of nearly 360 fragments of second growth forest that ranges from 1 to 300 ha. The landscape presents $31 \%$ of forest fragments in medium to late successional stages and $6 \%$ of early successional forests, totalling 37\% natural vegetation. The remaining area is composed of agricultural fields, pastures, exotic forest plantation and human infrastructure (Metzger 2003). Five km east of the fragmented landscape, over the same geomorphologic unit, lies the Morro Grande Forest Reserve (23⒊' $-23^{\circ} 48^{\prime} \mathrm{S}$ and $46^{\circ} 47^{\prime}-46^{\circ} 55^{\prime} \mathrm{W}$ ), a 9.400 ha continuous late second growth forest well connected with the mature rainforest of the Paranapiacaba sierra.

\section{STUdiED SPECIES}

Five bird species were chosen considering three main criteria. Firstly, they were strictly forest species that exhibit territorial behaviour, thus being likely to respond to playback (J.M. Goerck, unpublished data, Stotz et al. 1996). Secondly, in order to consider species that perceive the landscape in different ways and present distinct sensitivity to the fragmentation of their habitat, the chosen species presented also diverse biological characteristics. Finally, all species were also non-migratory and can be found all year long at the study sites.

These species are (Table I): 1 - White-browed Warbler Basileuterus leucoblepharus, a small Parulidae weighing only $20 \mathrm{~g}$, found in montane forests. It feeds on insects, lives in the understory and is weakly affected by habitat fragmentation (Uezu et al. 2005). 2 - Giant Antshrike Batara cinerea, the biggest of the five species, weighing approximately $140 \mathrm{~g}$. It is an insectivorous Formicariidae that lives below the canopy and benefits from fragmentation in the Cotia region (Uezu et al. 2005). 
TABLE I

Selected bird species and their characteristics. In: insectivorous; Fr: frugivorous; Bc: below canopy; Ms: middle storey; Us: understorey.

\begin{tabular}{c|c|c|c|c|c}
\hline $\begin{array}{c}\text { Species } \\
\text { (common name) }\end{array}$ & Family & Weigh & $\begin{array}{c}\text { Feeding } \\
\text { habit }\end{array}$ & Habitat & $\begin{array}{c}\text { Sensitivity to } \\
\text { fragmentation }\end{array}$ \\
\hline $\begin{array}{c}\text { Basileuterus leucoblepharus } \\
\text { (White-browed Warbler) }\end{array}$ & Parulidae & $20 \mathrm{~g}$ & $\mathrm{In}$ & $\mathrm{Us}$ & Low \\
\hline $\begin{array}{c}\text { Batara cinerea } \\
\text { (Giant Antshrike) }\end{array}$ & Formicariidae & $140 \mathrm{~g}$ & $\mathrm{In}$ & $\mathrm{Bc}+\mathrm{Ms}$ & Low \\
\hline $\begin{array}{c}\text { Chiroxiphia caudata } \\
\text { (Swallow-tailed Manakin) }\end{array}$ & Pipridae & $25 \mathrm{~g}$ & $\mathrm{Fr}$ & $\mathrm{Ms}+\mathrm{Us}$ & Medium \\
\hline $\begin{array}{c}\text { Pyriglena leucoptera } \\
\text { (White-shouldered Fire-eye) }\end{array}$ & Formicariidae & $30 \mathrm{~g}$ & $\mathrm{In}$ & $\mathrm{Ms}+\mathrm{Us}$ & Medium \\
\hline $\begin{array}{c}\text { Trogon surrucura } \\
\text { (Surucua Trogon) }\end{array}$ & Trogonidae & $70 \mathrm{~g}$ & $\mathrm{Fr}$ & $\mathrm{Bc}$ & High \\
\hline
\end{tabular}

3 - Swallow-tailed Manakin Chiroxiphia caudata, a Pipridae weighing around $25 \mathrm{~g}$ known by its characteristic and intricate sexual behaviour (Foster 1981). The species is frugivorous, inhabits the intermediate strata of the forest and is moderately affected by habitat fragmentation (Uezu et al. 2005). 4 - White-shouldered Fire-eye Pyriglena leucoptera, another Formicariidae, weighing about $30 \mathrm{~g}$. This species is of medium sensitivity to fragmentation (Uezu et al. 2005) and lives in the middle and low storeys of the forest searching for insects (Sick 1997). 5 - Surucua Trogon Trogon surrucura, from the family Trogonidae, is a large frugivorous bird that weights approximately $70 \mathrm{~g}$. Because of its size and feeding habits, it is very susceptible to fragmentation (Goerck 1997), being present only in large forest fragments (Uezu et al. 2005).

\section{SONG RECORDINGS}

Male bird song or call recordings were obtained from the Arquivo Sonoro Neotropical (ASN) of the Universidade Estadual de Campinas (UNICAMP), Brazil. The vocalization of each species is distinctive and with unique characteristics (Fig. 1): A The song of B. leucoblepharus consists of a highpitched scale of descending notes; B - Batara cinerea vocalizes a long and trilled song with the last note shorter; $\mathrm{C}$ - The vocalization of $C$. caudata is characterized by strong calls usually, but not always, repeated for several times; D - The song of $P$. leucoptera is very penetrating in the forest and is characterized by an unvarying sequence of the same note; and E - Trogon surrucura sings a constant series of 14 to 17 notes with the last ones lower.

Song recordings were broadcasted using a Sony TCM-5000EV cassette tape recorder with the speaker positioned between one and two meters above the ground. The volume of the broadcast was set for human ears to hear it at a maximum distance of $100 \mathrm{~m}$. The intensity of the songs, measured with a Bruel \& Kjaer decibel meter positioned at $1 \mathrm{~m}$ from the speaker was: $79.2 \mathrm{~dB}$ for B. leucoblepharus, $81.6 \mathrm{~dB}$ for B. cinerea, $75.0 \mathrm{~dB}$ for $C$. caudata, $79.0 \mathrm{~dB}$ for P. leucoptera and $79.5 \mathrm{~dB}$ for $T$. surrucura.

\section{DAILY AND SEASONAL VARIATION OF PLAYBACK EFFICIENCY}

This experiment was conducted inside the continuous forest of the Morro Grande Forest Reserve between June 2000 and May 2001, in three distinct selected sites where all five species were known to be present and could be easily observed or heard all year long. In order to reduce the variance in 

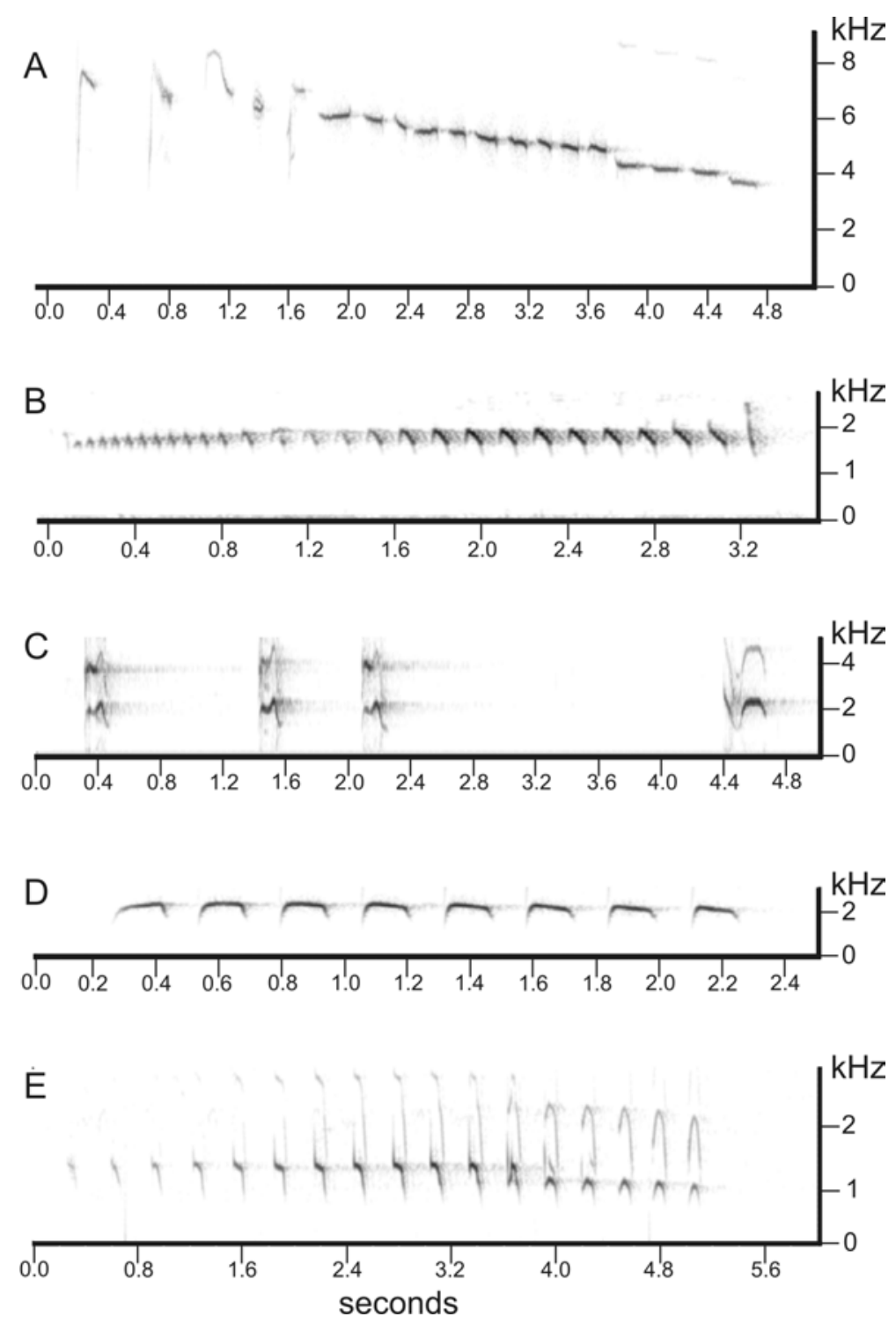

Fig. 1-Sonograms of the vocalizations used for each studied species for the playback surveys. A: B. leucoblepharus; B: B. cinerea; C: C. caudata; D: P. leucoptera; E: T. surrucura. Each sonogram is presented in a distinct scale of time (in seconds) and frequency (in $\mathrm{kHz}$ ). Extracted from the Arquivo Sonoro Neotropical (ASN), UNICAMP.

environmental conditions between sites, their selection was guided according to the forest type and structure. Playback sessions were conducted every separate month and for different times of the day. The sum of detected bird responses to the playback within each tested month or period of the day was termed detection efficiency. Therefore, efficiency values for a single species may vary from zero to the total number of playback sessions conducted at a given month or day period. In order to allow easier comparisons, these values were also standardised as percentages of positive response.

To assess detection efficiency in relation to time of the day, three different test periods were 
set: 1) during the two hours after sunrise; 2) at about two hours around noon and 3) during the two hours before sunset. At each period, three playback sessions were broadcasted for each one of the species at three different sampling points (nine playback sessions at nine different points per day). Each playback session was composed by one minute of playback, intercalated by thirty seconds of silence, to account for responsive birds (Johnson et al. 1981), until five minutes were completed (Morrell et al. 1991, Sliwa and Sherry 1992). To avoid the stimulation of the same bird more than once during the same period, sampling points were set at least $200 \mathrm{~m}$ away from each other (Sliwa and Sherry 1992). The sequence of species broadcasted was set randomly at each point. To prevent habituation of the birds to the recorded songs no sampling point was tested more than once a month (W.R. Silva, unpublished data).

At each session, the response by the birds was recorded as negative (no response) or positive. A response was considered positive when changes in the behaviour of the birds were detected after the playback begun. These changes were usually recognized as increased rate of vocalization and/or alterations in the movement of the birds towards the sound source. If an individual was detected closing in and/or circling around the sound source in silence during or after the playback, it was also documented as a responsive bird. Birds detected before the beginning of the playback but that did not show any changes in their behaviour demonstrating specific interest for the played song during or after the broadcast were noted as negative responders (no response). To identify how long it takes for each species to respond to the playback, the time elapsed between the beginning of the playback and the detection of positive response, termed as the latency time, was also noted. This was made in order to identify which is the minimum time that someone should wait for a response to take place before stating that the species is absent during that session. A short waiting time may lead to a decrease in the quantity of contacts by impeding the detection of late responsive birds. On the other hand, it would not be convenient to wait for periods longer than the mean latency time of the species added to its standard deviation, as it is unlikely that a bird responds after this and the species could then be documented as absent for the tested point without further loss of time. After the end of the last species broadcast, the observer (DB) waited for five additional minutes to account for birds with long latency of response. Playback was not carried out during rainy days due to noise interference (Johnson et al. 1981).

These procedures were repeated three days a month for twelve consecutive months. For each species, 27 playback sessions were conducted monthly, totalling 324 tests apiece, 108 at each period of the day. Differences in birds detection efficiency along the day were verified through G-tests in contingency tables, and when significant differences were detected $(\mathrm{P}<0.05)$ an a posteriori $\chi_{c}^{2}$ test (Zar 1999) was used. Detection efficiency throughout the year was tested with circular statistics, comparing the twelve months through the Rayleigh's test (Zar 1999), with a significance of $\mathrm{P}<0.05$.

\section{Playback Detection EfFiciency in Relation TO BIRD ABUNDANCE}

The outcomes of the experiment described above were used to determine the best period of the day and season of the year when the relationship between playback efficiency and bird abundance should be tested. To conduct that test, thirteen forest fragments ranging from 13 to 275 ha were studied. Fragment selection was conducted in order to reproduce Reserve sites environmental conditions. Inside each fragment, a grid of five to nine sampling points (depending on fragments area) located at least $200 \mathrm{~m}$ apart was set. The sites used before in the Morro Grande Forest Reserve were divided into three different sets of nine points and sampled again. The Reserve sets of nine points were originally placed at least $2 \mathrm{~km}$ apart of each other in order to simulate the spatial configuration of the fragments. Because the latency time of each species was already known, the species broadcasting 
sequence was set by this parameter, in order to increase bird detection probabilities. Consequently, the first broadcasted species was the one with highest latency time and the last with the shortest. Each study site (fragments or Reserve sites) was sampled for four different non-consecutive days at the best season of the year and time of the day. In each one of the four days, three sampling points were randomly selected for the playback trials, totalising twelve playback sessions per site and species for each one of the sixteen sites. Each site was surveyed with playback twice at sunrise and twice at noon, between 1 August and 29 September 2001.

The abundance information was estimated between May 2000 and April 2001 through passive point counts (Blondel et al. 1970, Vielliard and Silva 1990), at the same points used for the playback (Uezu et al. 2005). This was the best available abundance estimate for all studied species and could be used as a precise occurrence data at these sites. All fragments were sampled during early morning for one day every two months. At each day, one fragment was selected and five sample points were randomly chosen in it. Each point was observed for 20 minutes to account for present birds. By dividing the number of contacts, visual and/or auditory, by the number of sampled points an Index of Point Abundance (IPA) was then calculated for each species in each fragment.

To test if detection efficiency was related to bird abundance in the forest, three different methods were used. The playback-determined occurrence of the birds (dependent variable) was related with their abundance (IPA, independent variable) in a logistic regression (Ratcliffe et al. 1998). A Pearson correlation analysis (Zar 1999) was done between the response rates to the playback in each fragment and the IPA. The response rate was defined for each species as the quantity of positive responses in each site divided by twelve, the total number of playback sessions conducted after four survey days. Finally, the percentage of sites where the playback correctly attested the presence of the birds (defined by point counts results) was calculated. To verify how many visits to the fragments were needed for the playback to acquire a similar occurrence pattern as obtained by point counts, the three above explained methods were conducted for all possible combinations of one, two, three and four survey days.

\section{RESULTS}

Detection EFFICIENCY IN RELATION to THE Time of DAY AND SEASON OF THE YEAR

The species with the highest percentages of positive responses inside the Reserve was B. leucoblepharus (Table II). Mean latency time varied between species from 2 to 8.3 minutes (Table III). The analysis of variance showed that latency times were significantly different among species $\left(\mathrm{F}_{4}=41.16\right.$; $\mathrm{P}<0.01)$. The a posteriori test indicated that the latency time of $B$. cinerea was significantly longer than any other tested species $(\mathrm{P}<0.01)$. The latency presented by $C$. caudata was different from that of T. surrucura $(\mathrm{P}<0.01)$ but not of $B$. leucoblepharus $(\mathrm{P}=0.80)$. No significant differences were found between $P$. leucoptera and T. surrucura $(\mathrm{P}=0.58)$ or between $P$. leucoptera and $C$. caudata $(\mathrm{P}=0.27)$.

Three species, B. leucoblepharus, C. caudata and $T$. surrucura showed significant differences in detection efficiency according to the period of the day (Table III). The a posteriori $\chi_{c}^{2}$ test indicated that the efficiency at sunrise and noon was significantly higher in comparison with the period just before sunset (Table III).

According to the Rayleigh's test, the only species to present a mean season of higher efficiency was B. cinerea $\left(\mathrm{z}_{0.05,88}=6.041 ; \mathrm{P}<0.01\right.$, Fig. 2). All other species had uniform distributions of efficiency throughout the twelve tested months (Fig. 2). The mean period of higher efficiency for $B$. cinerea was July and August, but considering the low concentration of responses $(r=0.262)$, one can perceive that this is only the central tendency of a larger period of five consecutive months ranging from June to October. Those five months presented no significant difference between each other along the given period $\left(\mathrm{G}_{4}=3.807 ; \mathrm{P}>0.25\right)$. Responses from June 
TABLE II

Percentages of detected positive responses to playback according to each tested period of the day and month for the five studied species.

\begin{tabular}{c|c|c|c|c|c|c}
\hline & & B. leucoblepharus & B. cinerea & C. caudata & P. leucoptera & T. surrucura \\
\hline \multirow{4}{*}{\begin{tabular}{c} 
Periods $\begin{array}{c}\text { of the } \\
\text { day }\end{array}$ \\
\cline { 2 - 7 }
\end{tabular}} & Sunrise & 77.8 & 27.8 & 61.1 & 39.8 & 53.7 \\
\cline { 2 - 7 } & Noon & 72.2 & 25.9 & 61.1 & 28.7 & 45.4 \\
\hline \multirow{5}{*}{} & January & 58.3 & 27.8 & 41.7 & 36.1 & 25.9 \\
\cline { 2 - 7 } & February & 48.1 & 14.8 & 59.3 & 40.7 & 25.9 \\
\cline { 2 - 7 } & March & 70.4 & 2.2 & 55.6 & 44.4 & 22.2 \\
\cline { 2 - 7 } & April & 81.5 & 3.7 & 44.4 & 33.3 & 55.6 \\
\cline { 2 - 7 } & May & 70.4 & 29.6 & 51.9 & 22.2 & 55.6 \\
\cline { 2 - 7 } & June & 66.7 & 22.2 & 59.3 & 29.6 & 44.4 \\
\cline { 2 - 7 } & July & 70.4 & 48.1 & 77.8 & 29.6 & 59.3 \\
\cline { 2 - 7 } & August & 70.4 & 40.7 & 33.3 & 25.9 & 51.9 \\
\cline { 2 - 7 } & September & 59.3 & 25.9 & 33.3 & 33.3 & 18.5 \\
\cline { 2 - 7 } & October & 88.9 & 40.7 & 48.1 & 48.1 & 25.9 \\
\cline { 2 - 7 } & November & 70.4 & 48.1 & 70.4 & 33.3 & 55.6 \\
\cline { 2 - 7 } & December & 70.4 & 14.8 & 59.3 & 37.0 & 44.4 \\
\hline
\end{tabular}

\section{TABLE III}

Mean latency values (in minutes) and playback positive (pos) and negative (neg) responses according to the period of the day for the five studied species ( $N=108$ for each species and period) inside the Morro Grande Forest Reserve. P: significance level.

\begin{tabular}{|c|c|c|c|c|c|c|c|c|c|c|}
\hline \multirow{3}{*}{ Species } & \multirow{3}{*}{ Latency $\mathrm{N}^{*}$} & \multicolumn{6}{|c|}{ Playback responses } & \multirow{3}{*}{$\begin{array}{c}\mathrm{G} \text { test } \\
\mathrm{sr} \times \mathrm{nn} \times \mathrm{st} \\
\mathrm{G}_{(2)}(\mathrm{P})\end{array}$} & \multicolumn{2}{|c|}{ a posteriori $\chi_{c}^{2}$} \\
\hline & & \multicolumn{2}{|c|}{$\begin{array}{c}\text { Sunrise } \\
(\mathrm{sr})\end{array}$} & \multicolumn{2}{|c|}{$\begin{array}{l}\text { Noon } \\
(\mathrm{nn})\end{array}$} & \multicolumn{2}{|c|}{$\begin{array}{c}\text { Sunset } \\
\text { (st) }\end{array}$} & & $\begin{array}{c}(\mathrm{sr}+\mathrm{nn}) \times \mathrm{st} \\
\chi_{c(1)}^{2}(\mathrm{P})\end{array}$ & $\begin{array}{l}\mathrm{sr} \times \mathrm{nn} \\
\chi_{c(1)}^{2}(\mathrm{P})\end{array}$ \\
\hline & & pos & neg & pos & neg & pos & neg & & & \\
\hline B. leucoblepharus & $\begin{array}{c}2.0 \pm 1.9 \\
225\end{array}$ & 84 & 24 & 78 & 30 & 63 & 45 & $\begin{array}{c}10.09 \\
(\mathrm{P}<0.01)\end{array}$ & $\begin{array}{c}8.65 \\
(\mathrm{P}<0.01)\end{array}$ & $\begin{array}{c}0.62 \\
(\mathrm{P}>0.25)\end{array}$ \\
\hline B. cinerea & $\begin{array}{c}8.3 \pm 8.1 \\
88\end{array}$ & 30 & 78 & 28 & 80 & 30 & 78 & $\begin{array}{c}0.12 \\
(\mathrm{P}>0.9)\end{array}$ & & \\
\hline C. caudata & $\begin{array}{c}2.6 \pm 2.6 \\
177\end{array}$ & 66 & 42 & 66 & 42 & 45 & 63 & $\begin{array}{c}10.99 \\
(\mathrm{P}<0.01)\end{array}$ & $\begin{array}{c}10.21 \\
(\mathrm{P}<0.01)\end{array}$ & $\begin{array}{c}0.02 \\
(\mathrm{P}>0.99)\end{array}$ \\
\hline P. leucoptera & $\begin{array}{c}3.6 \pm 4.1 \\
113\end{array}$ & 43 & 65 & 31 & 77 & 39 & 69 & $\begin{array}{c}3.08 \\
(\mathrm{P}>0.1)\end{array}$ & & \\
\hline T. surrucura & $\begin{array}{c}4.2 \pm 5.1 \\
135\end{array}$ & 58 & 50 & 49 & 59 & 28 & 80 & $\begin{array}{c}18.58 \\
(\mathrm{P}<0.01)\end{array}$ & $\begin{array}{c}15.56 \\
(\mathrm{P}<0.01)\end{array}$ & $\begin{array}{c}1.18 \\
(\mathrm{P}>0.9)\end{array}$ \\
\hline
\end{tabular}

* The numbers of observations $(\mathrm{N})$ are unequal between species because latency times could only be accounted after positive responses. 


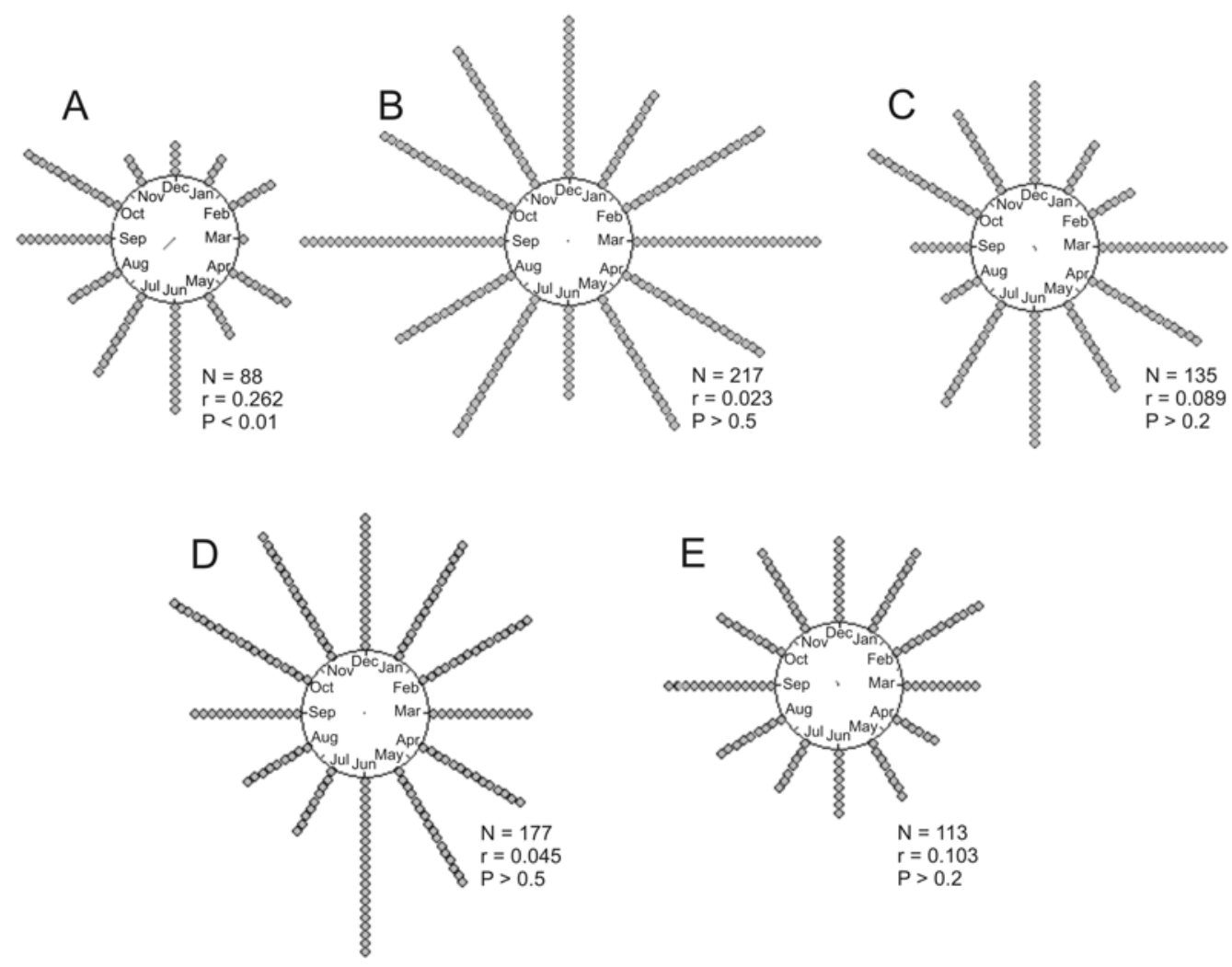

Fig. 2 - Distribution of positive responses (gray dots) to the playback during one year of surveys and Rayleigh's test results. A: B. cinerea; B: B. leucoblepharus; C: T. surrucura; D: C. caudata; E: P. leucoptera. $\mathrm{N}$ : number of playback sessions; r: concentration level, P: significance level.

to October were also compared to responses from the rest of the year, confirming that this was the period of highest playback efficiency to detect $B$. cinerea in the forest (McNemar's test, $\chi_{c 1}^{2}=5.1127$; $\mathrm{P}<0.025)$.

\section{DETECTION EFFICIENCY ACCORDING TO THE} ABUNDANCE OF THE BIRDS INSIDE

\section{FOREST FRAGMENTS}

Three species were detected in all sampled sites by both the playback and the point counts (Table IV). The two methods presented similar species occurrence results, except for two fragments where T. surrucura and P. leucoptera were detected only by point counts but not by playback (Table IV). In both cases, species abundance (IPA) was low, indicating that the playback was deficient in detecting occurrence only when IPA was less than 0.05 .

Logistic regression was calculated only for $T$. surrucura since it was the only species not present at all sampled sites. One single survey day was enough to incur into a significant regression, indicating a strong relation between the two tested variables (Table V).

The correlation analyses showed contrasting results. For three species, B. cinerea, C. caudata and $P$. leucoptera, almost no correlation between playback response rate and IPA were observed for any of the 16 possible combinations (Table VI). For $B$. leucoblepharus and $T$. surrucura, nearly all possible combinations had significant positive correlations, showing a strong influence of the abundance on the detection by playback.

For all species, the percentage of sites where 
TABLE IV

Number of positive responses for each study site obtained after twelve playback sessions per species and abundance values (IPA) in parenthesis (Uezu et al. 2005). Cases where IPA and playback results disagreed are marked with *.

\begin{tabular}{l|c|c|c|c|c}
\hline Fragments & B. leucoblepharus & B. cinerea & C. caudata & P. leucoptera & T. surrucura \\
\hline Mioko & $5(0.71)$ & $7(0.73)$ & $9(1.03)$ & $5(0.14)$ & $1(0.11)$ \\
\hline Takimoto & $5(0.89)$ & $3(0.53)$ & $9(1.31)$ & $8(0.26)$ & $6(0.23)$ \\
\hline Pedro & $8(1.43)$ & $6(0.70)$ & $10(1.60)$ & $5(0.34)$ & $3(0.11)$ \\
\hline Pedroso & $4(1.69)$ & $6(0.30)$ & $5(1.14)$ & $2(0.37)$ & $1(0.34)$ \\
\hline Zezinho & $2(0.31)$ & $5(0.30)$ & $10(1.03)$ & $3(0.26)$ & $4(0.23)$ \\
\hline Lila & $3(0.34)$ & $5(0.13)$ & $8(1.03)$ & $3(0.17)$ & $0(0.00)$ \\
\hline Dito-André & $6(0.89)$ & $9(0.63)$ & $9(0.77)$ & $5(0.20)$ & $0(0.00)$ \\
\hline Beto & $6(0.96)$ & $9(0.50)$ & $7(1.18)$ & $5(0.32)$ & $0(0.00)$ \\
\hline Lacerda & $4(0.25)$ & $10(0.38)$ & $9(1.46)$ & $0(0.04) *$ & $0(0.00)$ \\
\hline Godoy & $9(1.00)$ & $6(0.50)$ & $8(1.18)$ & $3(0.43)$ & $0(0.00)$ \\
\hline Nelson & $9(1.69)$ & $8(0.43)$ & $8(0.63)$ & $7(0.54)$ & $0(0.00)$ \\
\hline Reizinho & $5(1.43)$ & $6(0.37)$ & $5(0.94)$ & $3(0.29)$ & $0(0.00)$ \\
\hline Agostinho & $11(1.40)$ & $3(0.47)$ & $10(0.89)$ & $6(0.23)$ & $0(0.03) *$ \\
\hline Reserve A & $10(2.09)$ & $4(0.23)$ & $7(1.11)$ & $2(0.34)$ & $6(0.23)$ \\
\hline Reserve B & $6(1.34)$ & $1(0.27)$ & $8(1.40)$ & $1(0.31)$ & $8(0.51)$ \\
\hline Reserve C & $8(1.37)$ & $5(0.23)$ & $10(1.26)$ & $8(0.26)$ & $9(0.17)$ \\
\hline
\end{tabular}

TABLE V

Logistic regression between species occurrences according to playback results and to abundance index (IPA) for T. surrucura. "Combination" indicates which survey days $(a, b, c, d)$ were utilized in each test. P: significance level. $\mathrm{BO}$ is the estimated logistic coefficient.

\begin{tabular}{|c|c|c|c|}
\hline Quantity of survey days & Combination & Logistic regression & \\
\hline & & $\mathrm{B} 0$ & $\mathrm{P}$ \\
\hline \multirow{4}{*}{1} & $\mathrm{a}$ & -3.40 & 0.02 \\
\hline & $\mathrm{b}$ & -2.31 & $<0.01$ \\
\hline & $\mathrm{c}$ & -2.25 & $<0.01$ \\
\hline & $\mathrm{d}$ & -3.08 & $<0.01$ \\
\hline \multirow{6}{*}{2} & $a+b$ & -2.31 & $<0.01$ \\
\hline & $a+c$ & -2.51 & $<0.01$ \\
\hline & $a+d$ & -3.08 & $<0.01$ \\
\hline & $b+c$ & -6.12 & $<0.01$ \\
\hline & $\mathrm{b}+\mathrm{d}$ & -2.51 & $<0.01$ \\
\hline & $\mathrm{c}+\mathrm{d}$ & -6.12 & $<0.01$ \\
\hline \multirow{4}{*}{3} & $a+b+c$ & -6.12 & $<0.01$ \\
\hline & $a+b+d$ & -2.31 & $<0.01$ \\
\hline & $a+c+d$ & -6.12 & $<0.01$ \\
\hline & $\mathrm{b}+\mathrm{c}+\mathrm{d}$ & -6.12 & $<0.01$ \\
\hline 4 & $a+b+c+d$ & -6.12 & $<0.01$ \\
\hline
\end{tabular}




\section{TABLE VI}

Pearson correlations coefficients $\left(r^{2}\right)$ between the efficiency of the playback and the abundance index values (IPA) for all species and all possible combinations of survey days (a, b, c, d).

\begin{tabular}{|c|c|c|c|c|c|c|}
\hline $\begin{array}{l}\text { Quantity of } \\
\text { survey days }\end{array}$ & Combinations & $\begin{array}{l}\text { B. leucoble- } \\
\text { pharus }\end{array}$ & B. cinerea & C. caudata & P. leucoptera & T. surrucura \\
\hline \multirow{4}{*}{1} & $\bar{a}$ & $0.39 *$ & 0.03 & 0.05 & 0.00 & $0.26^{*}$ \\
\hline & $\mathrm{b}$ & 0.23 & 0.10 & 0.08 & $0.34 *$ & $0.38 *$ \\
\hline & $\mathrm{c}$ & $0.47 *$ & 0.05 & 0.10 & 0.00 & $0.36^{*}$ \\
\hline & $\mathrm{d}$ & 0.05 & 0.03 & 0.01 & 0.00 & $0.47 *$ \\
\hline \multirow{6}{*}{2} & $a+b$ & $0.50 *$ & 0.16 & 0.11 & 0.17 & $0.49 *$ \\
\hline & $a+c$ & $0.61 *$ & 0.05 & 0.00 & 0.00 & $0.36^{*}$ \\
\hline & $a+d$ & $0.34 *$ & 0.06 & 0.06 & 0.00 & $0.40 *$ \\
\hline & $\mathrm{b}+\mathrm{c}$ & $0.42 *$ & 0.16 & 0.00 & 0.09 & $0.57 *$ \\
\hline & $\mathrm{b}+\mathrm{d}$ & 0.16 & 0.07 & 0.09 & 0.15 & $0.48 *$ \\
\hline & $\mathrm{c}+\mathrm{d}$ & $0.25 *$ & 0.07 & 0.02 & 0.00 & $0.52 *$ \\
\hline \multirow{4}{*}{3} & $a+b+c$ & $0.60 *$ & 0.14 & 0.02 & 0.07 & $0.54 *$ \\
\hline & $a+b+d$ & $0.37 *$ & 0.12 & 0.12 & 0.08 & $0.50^{*}$ \\
\hline & $a+c+d$ & $0.48 *$ & 0.07 & 0.00 & 0.00 & $0.45^{*}$ \\
\hline & $\mathrm{b}+\mathrm{c}+\mathrm{d}$ & $0.29 *$ & 0.12 & 0.00 & 0.06 & $0.57 *$ \\
\hline 4 & $a+b+c+d$ & $0.47 *$ & 0.13 & 0.03 & 0.05 & $0.54 *$ \\
\hline
\end{tabular}

$* \mathrm{P}<0.05$.

the playback correctly attested the bird presence increased with the sampling effort (Fig. 3). For two species, B. leucoblepharus and B. cinerea, maximum success ( $100 \%$ of correct presence detection) was obtained with three survey days. Two days were enough to obtain maximum success for $C$. caudata. The remaining two species did not reach $100 \%$ of accuracy: the highest success for P. leucoptera was around $95 \%$ and for T. surrucura around $90 \%$.

\section{DISCUSSION}

Playback Detection Efficiency: Time of the DAY AND SEASON INFLUENCES

For three species the best periods of the day to conduct playback census were just after sunrise and at noon. This is in compliance with the daily peak of spontaneous activity of some species, such as $C$. caudata. This species presents a period of higher spontaneous activity between sunrise and 15:00, the main period of sexual activity (Foster 1981). Because of the strong vocal interaction of the males, derived from their complex courting behaviour, individuals shall be more prone to react to intruders (in this case the broadcasted song) during this period, leading to higher method efficiency.

On the other hand, some passive point counts studies tend to disagree with this result, considering sunrise as the best period for bird surveys, followed by sunset and at last noon (Järvinen et al. 1977, Robbins 1978, Bibby et al. 1993). G.S. Betini (unpublished data) detected that T. surrucura, P. leucoptera and Basileuterus culicivorus, a species closely related to $B$. leucoblepharus, were spontaneously more active during early morning in contrast to the rest of the day, when their vocal activity was lower.

These results suggested that for these species the playback increased the time period when bird census should be conducted to acquire the highest efficiency from sunrise to the entire morning, up to noon. Otherwise, the playback may induce birds to become detectable at any time, maintaining the quantity of contacted individuals equal along 

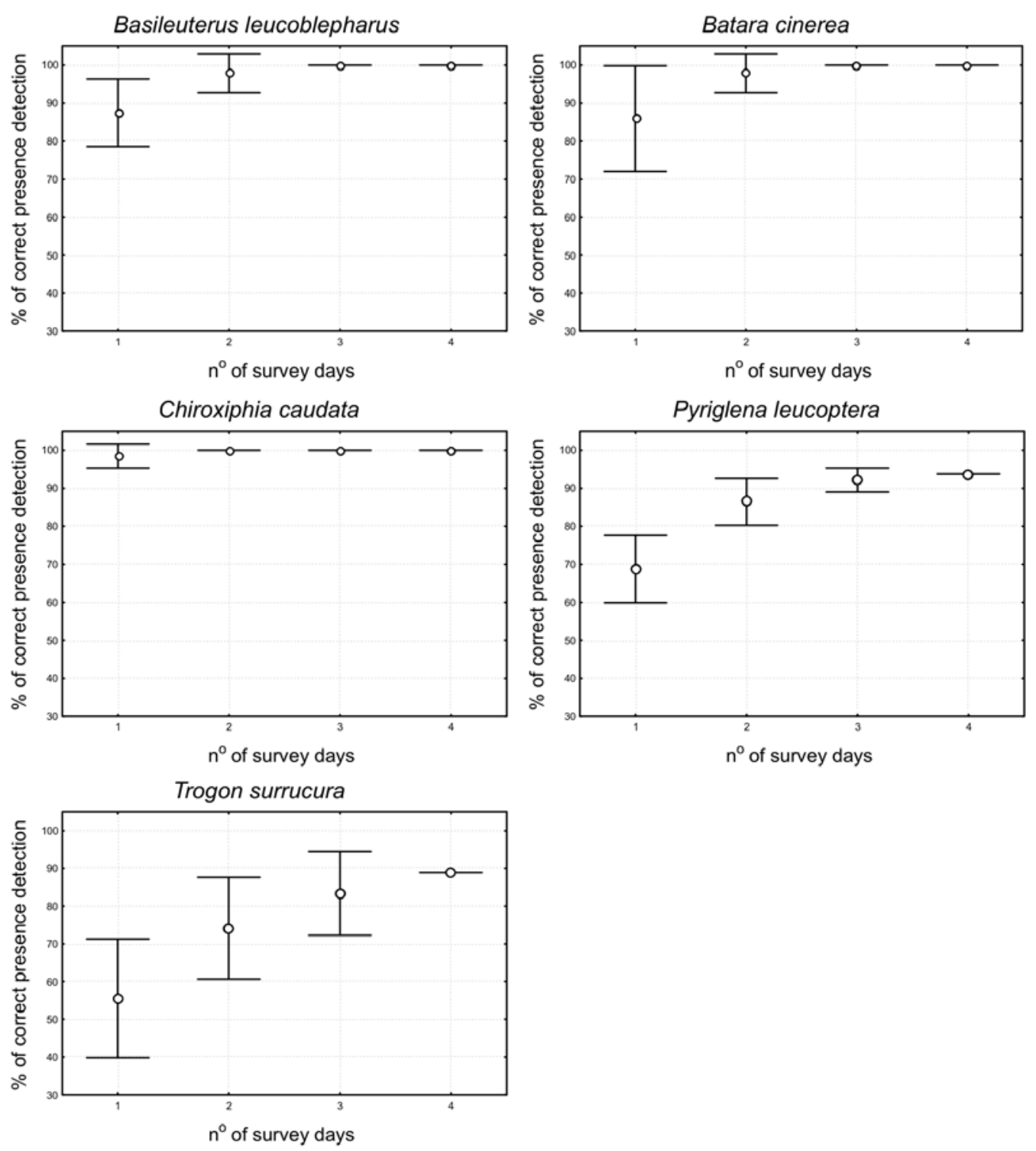

Fig. 3 - Percentages $( \pm \mathrm{SD})$ of sites where the playback correctly detected the presence of each species according to the number of survey days. Sites where IPA= 0.0 were omitted.

the day, in contrast to the census without playback. This was observed for P. leucoptera at the present study and for Dendroica caerulescens in Jamaica (Sliwa and Sherry 1992), which leads to the pattern of no daily variation in bird detection presented by these species. Of course, in this case the playback had also increased the survey period to further than merely sunrise.
The only species with significant seasonal variation in playback response was $B$. cinerea, which should be surveyed between June and October to acquire maximum census efficiency. This is in accordance with the pattern found by A. Uezu (unpublished data), who recorded a more intense peak of spontaneous vocal activity of this species between July and September. The annual period of greater 
playback efficiency may be linked to the reproductive biology of the species. Many authors use the reproductive season to proceed with avifaunal surveys (Dawson 1981, Mayfield 1981, Greenwood et al. 1995, Clergeau and Burel 1997, Ratcliffe et al. 1998, Drapeau et al. 2000), when individuals are reinforcing their dominance or establishing new territories and consequently are more active. For this reason, they may be more prone to confront intruders, increasing the chances of response to playback.

However, contrary to the expected, for four of our species there was no seasonal variation in playback efficiency. Even in non-reproductive months, the birds kept responding with the same intensity to the playback, producing no significant variation in the quantity of contacts along the tested year. This suggests that playback may be used as a survey method for these bird species all year long and not only during the reproductive season. This might be related to the active stimulation of the birds or may come from a strong bond of the individuals to their territories.

Playback Detection Efficiency According to BIRD ABUNDANCE

Playback was a very efficient technique to detect the presence of these species in all sampled sites where the point counts detected the occurrence of the birds. It incurred in correct presence/absence detection in at least $98 \%$ of the studied cases. However, there was not always a direct relationship between the abundance of the birds and the detection efficiency.

For B. leucoblepharus and T. surrucura there was a significant positive relationship between the response rate and IPA, indicating that playback capacity to identify sites where the species is present increased with the abundance. According to Schieck (1997) vocalizations with frequencies higher than $2 \mathrm{kHz}$ may suffer strong attenuation in the forest. Aubin et al. (2002, 2004) stated that the song of B. leucoblepharus is particularly high-pitched and susceptible to a strong attenuation when propagating through dense vegetation. In those cases, playback will be efficient to identify only close birds, since the playback can only reach nearby individuals. But, even if the song functional structure is preserved (Aubin et al. 2002), allowing birds farther away to recognize their specific vocalization, the observer may not have the same ability, decreasing the quantity of contacts proportionally to the abundance.

The significant relationship found for Trogon surrucura is probably an effect of the rarity of the species. According to several researchers (Willis 1979, Christiansen and Pitter 1997, Marini 2001, Marsden et al. 2001), trogons are highly affected by patch size, being present only in large fragments or reserves and in low abundance, as detected in the current study (Uezu et al. 2005). Usually, big canopy frugivorous birds are rare and need large areas to search for food (Goerck 1997, Price et. al. 1999). The size of each individual territory was thus presumably large in relation to the distance between sample points. As the abundance increases, territories might overlap or decrease in size (Sherman and Eason 1998) and contact with the birds may become more frequent, increasing detection rates along with the number of present birds in the forest.

On the other hand, there was a lack of correlation between the response rate and IPA for three species. In the case of $C$. caudata, the lack of correlation may be an effect of the sexual behaviour of the species. Male manakins are constantly engaged in vocal duels for dominance in the hierarchy of the group (Foster 1981) and present a natural aggressive behaviour that makes the individuals extremely responsive, increasing the detection rate after playback. So, even in low abundance sites, the quantity of contacts shall be high.

For B. cinerea, the lack of correlation was not due to the behaviour of the individuals but to the properties of its vocalization. This species song is very loud and the responsive individual was frequently far away from the playback source, indicating that the song could travel long distances in the forest and still be recognizable for the receiver. As a result, individuals might still be able to identify 
and respond to the broadcasted song even if they are further than $100 \mathrm{~m}$ from the sound source. Because of that, even in places with low abundance, it is possible to locate distant individuals, creating the non-correlation pattern.

In the case of P. leucoptera no results pointed out to any clear cause to the lack of correlation between detection efficiency and abundance. The detected pattern of response may be related not only to bird abundance. For instance, if for any reason the access to food resources decline at a certain site, individual birds may tend to become more aggressive in order to defend their territories (Armstrong 1991, Carrascal et al. 1998) and therefore more responsive to playback. In places of higher resource availability, even if the species is more abundant, there is no need to defend each territory so strongly and the response rate may then decrease. Therefore, the abundance of a species did not appear to be the sole or main factor to influence the occurrence detection efficiency of these birds. According to each species, other factors may modify this relationship.

\section{EFFECTS OF SAMPLING EFFORT}

According to Bibby et al. (2000) the chances of detecting new individuals should increase along with the sample effort, independently of the sampling method. That was the case for all species, since the proportion of correct presence detection through playback increased continuously with the number of survey days. The main question here is how large should the sampling effort be to obtain an accurate incidence data set, without wasting more time than necessary at a single site, in order to be able to quickly sample a large number of sites? Considering a confidence threshold of $90 \%$, one visit was enough to accurately detect $C$. caudata, while two visits were necessary for B. leucoblepharus and B. cinerea, and three for P. leucoptera. For T. surrucura, four visits were necessary to obtain a confidence value close to $90 \%$. For a confidence of $100 \%$, two visits were necessary for $C$. caudata and three for B. leucoblepharus and B. cinerea. In the case of $P$. leucoptera and $T$. surrucura, the propor- tion of correct detection did not reach $100 \%$ after four visits due to fragments with very low abundance. There was a threshold of approximately 0.05 of IPA, below which the bird detection through playback is improbable for a sampling effort of four days. An increase of the sampling effort could solve this problem.

\section{CONCLUSION}

The results of the present study pointed out to a large variation in Atlantic Forest bird species response to playback and to the importance of methodological studies in order to standardize census methods. Future researchers should try to understand each species behaviour before applying the method. If known, the latency time and the variation of playback responses according to the time of the day, season of the year, abundance and sampling effort could help to reduce the problem of "false absence" detections and maximize the efficiency of the playback to collect occurrence data, assuring good results for quick access surveys.

When compared to passive methods, the playback expanded the favourable time to conduct avifaunal surveys for these Atlantic Forest birds from the first hours of the day to the entire morning, up to noon. Also the season of the year is not an impediment to census these birds with playback. Four of the five studied species might be surveyed with the same efficiency of detection all year long. Barring when the abundance is too low, the playback technique can detect with only three survey days per site the occurrence pattern of these birds as accurately as the passive point counts. These patterns may also be applied to other bird species not studied in the present work.

\section{ACKNOWLEDGMENTS}

This research was part of the thematic project "Biodiversity conservation in fragmented landscapes at the Atlantic Plateau of São Paulo" and was financially supported by the Programa de Pesquisas em Caracterização, Conservação e Uso Sustentável 
da Biodiversidade da Fundação de Amparo à Pesquisa do Estado de São Paulo (BIOTA-FAPESP) (n. 99/05123-4; master fellowship for DB n. 00/01358-6). We would like to thank Ilse Storch, Wesley R. Silva and José Carlos Motta Jr who reviewed previous versions of this manuscript and José Roberto Nali along with all the staff from Companhia de Saneamento Básico do Estado de São Paulo (SABESP) and the Morro Grande Forest Reserve for their hospitality and support.

\section{RESUMO}

A técnica de play-back é muito útil para a detecção de aves, mas este método geralmente não é padronizado. Sua eficiência em atestar a ocorrência de cinco espécies de aves da Mata Atlântica (Pula-pula-assobiador Basileuterus leucoblepharus, Batará Batara cinerea, Tangará Chiroxiphia caudata, Olho-de-fogo Pyriglena leucoptera e Surucuá-de-barriga-vermelha Trogon surrucura) foi analisada de acordo com o horário do dia, estação do ano e abundância das espécies na Reserva Florestal do Morro Grande (São Paulo, Brasil) e em treze fragmentos florestais de uma paisagem adjacente. Gravações das vocalizações foram emitidas mensalmente ao amanhecer, meio do dia e entardecer, durante um ano. Para B. leucoblepharus, $C$. caudata e T. surrucura, o amanhecer e o meio do dia apresentaram-se mais eficientes que o entardecer. Batara cinerea apresentou maior eficiência de julho a outubro. O uso do play-back aumentou o período de maior eficiência dos levantamentos de aves em matas tropicais, comumente restrito ao período da manhã durante a estação reprodutiva. A técnica utilizada foi eficiente na detecção da ocorrência de todas as espécies, salvo quando sua abundância se apresentou muito baixa. Porém, apenas B. leucoblepharus e T. surrucura apresentaram abundância significativa e positivamente relacionada com essa eficiência. O presente estudo proporciona uma indicação precisa sobre o melhor horário do dia e época do ano, assim como um intervalo de confiança, com o intuito de aumentar a eficiência do play-back em detectar a ocorrência dessas espécies.

Palavras-chave: play-back, aves, fragmentos florestais, desenvolvimento metodológico, Mata Atlântica, Estado de São Paulo.

\section{REFERENCES}

ARMSTRONG DP. 1991. Aggressiveness of breeding territorial honeyeaters corresponds to seasonal changes in nectar availability. Behav Ecol Sociobiol 29: $103-111$.

Aubin T, Mathevon N, Vielliard JME and Silva ML. 2002. How an inadequate acoustic signal succeeds in the extreme environment of a tropical forest? The song of the White-browed Warbler. Beijing, China: Abstracts XXIII Int Ornith Congr.

Aubin T, Mathevon N, Silva ML, Vielliard JME AND SEBE F. 2004. How a simple and stereotyped acoustic signal transmits individual information: the song of the White-browed Warbler Basileuterus leucoblepharus. An Acad Bras Cienc 76: 335-344.

BibBy CJ, Burgess ND And Hill DA. 1993. Bird Census Techniques. San Diego: Academic Press.

Bibby CJ, Burgess ND, Hill DA and Mustoe SH. 2000. Bird Census Techniques. $2^{\text {nd }}$ ed., San Diego: Academic Press.

Blondel J, Ferry C and Frochot B. 1970. La méthode des indices ponctuels d'abondance (I.P.A.) ou des relevés d'avifaune par "stations d'écoute". Alauda 38: 55-71.

Carrascal LM, Senar JC, Mosetich i, Uribe F AND DOMENECH J. 1998. Interactions among environmental stress, body condition, nutritional status, and dominance in Great Tits. Auk 115: 727-738.

Catchrole CK and Slater PJB. 1995. Bird Song: Biological themes and variations. Cambridge: Cambridge University Press.

Christiansen MM And PitTer E. 1997. Species loss in a forest bird community near Lagoa Santa in Southeastern Brazil. Biol Conserv 80: 23-32.

Clergeau P And Burel F. 1997. The role of spatiotemporal patch connectivity at the landscape level: an example in a bird distribution. Landscape and Urban Planning 38: 37-43.

DAWSON DG. 1981. Counting birds for a relative measure (index) of density. In: RALPH CJ AND SCOTT JM (Eds), Estimating the numbers of terrestrial birds. Studies in Avian Biology 6: 12-16.

Drapeau P, Leduc A, Giroux JF, Savard JPL, BERGERON Y AND VICKERY WL. 2000. Landscape-scale disturbances and changes in bird com- 
munities of boreal mixed-wood forests. Ecol Monogr 70: 423-444.

Foster MS. 1981. Cooperative behaviour and social organization of the Swallow-tailed Manakin (Chiroxiphia caudata). Behav Ecol Sociobiol 9: 167-177.

GLAHN JF. 1974. Study of breeding rails with recorded calls in north-central Colorado. Wilson Bull 86: 206-214.

GoercK JM. 1997. Patterns of rarity in the birds of the Atlantic Forest of Brazil. Conserv Biol 11: 112-118.

Greenwood JJD, BAILlie SR, GRegory RD, PeAch WJ AND Fuller RJ. 1995. Some new approaches to conservation monitoring of British breeding birds. Ibis 137: 16-28.

HANSKI I. 1994. Patch-occupancy dynamics in fragmented landscapes. Trends Ecol Evol 9: 131-135.

JÄRVINEN O, VÄISÄNEN RA AND HAILA Y. 1977. Bird census results in different years, stages of the breeding season and times of the day. Ornis Fennica 54: 108-118.

JOHNSON RR AND DINSMORE JJ. 1986. The use of tape-recorded calls to count Virginia Rails and Soras. Wilson Bull 98: 303-306.

JOHNSON RR, BROWN BT, HAIGHT LT AND SIMPSON JM. 1981. Playback recording as a special avian censusing technique. In: RALPH CJ AND SCOTT JM (Eds), Estimating the numbers of terrestrial birds. Studies in Avian Biology 6: 68-75.

Kaufmann GW. 1988. The usefulness of taped Spotless Crake calls as a census technique. Wilson Bull 100: 682-686.

KöPPEN W. 1948. Climatologia. Mexico City: Ed Fondo Cultura Economica.

LindenMAYER DB, MCCARTHY MA AND POPE ML. 1999. Arboreal marsupial incidence in eucalypt patches in south-eastern Australia: a test of Hanski's incidence function metapopulation for patch occupancy. Oikos 84: 99-109.

MARINI MA. 2001. Effects of forest fragmentation on birds of the cerrado region, Brazil. Bird Conserv Intern 11: 13-25.

Marsden SJ, Whiffin M And Galetti M. 2001. Bird diversity and abundance in forest fragments and Eucalyptus plantations around an Atlantic forest reserve, Brazil. Biodiv Conserv 10: 737-751.
MAYFIELD HF. 1981. Problems in estimating population size through counts of singing males. In: RALPH CJ AND SCOTT JM (Eds), Estimating the numbers of terrestrial birds. Studies in Avian Biology 6: 220224.

MetzGer JP (Coord). 2003. Biodiversity conservation in fragmented landscapes at the Atlantic Plateau of São Paulo. São Paulo: Scientific report to the BIOTA-FAPESP program.

Milligan M. 1966. Vocal responses of White-crowned Sparrows to recorded songs of their own and another species. Anim Behav 14: 356-361.

MøLLER AP. 1992. Interspecific response to playback of bird song. Ethology 90: 315-320.

Morrell TE, YAHNER RH AND HARKNess WL. 1991. Factors affecting detection of Great Horned Owls by using broadcast vocalizations. Wildlife Soc Bull 19: 481-488.

Mosher JA AND FULLER MR. 1996. Surveying woodland hawks with broadcasts of Great Horned Owl vocalizations. Wildlife Soc Bull 24: 531-536.

Mosher JA, Fuller MR AND Kopeny M. 1990. Surveying woodland raptors by broadcast of conspecific vocalizations. J Field Ornith 61: 453-461.

PRice OF, Woinarski JZ AND Robinson D. 1999. Very large area requirements for frugivorous birds in monsoon rainforests of the Northern Territory, Australia. Biol Conserv 91: 169-180.

Ratcliffe N, Vughan D, Whyte C and ShepHERD M. 1998. Development of playback census methods for Storm Petrels Hydrobates pelagicus. Bird Study 45: 302-312.

RoBbins CS. 1978. Census techniques for forest birds. In: Degraed RM (Ed), Management of southern forest for nongame birds. Atlanta: USDA General Technical Report SE-GTR 14: 142-163.

Rosenfield RN, BIELEFELdT J, ANDERSON RK AND SMITH WA. 1985. Taped calls as an aid in locating Cooper's Hawk nests. Wildlife Soc Bull 13: 62-63.

Ross JLS AND MOROZ IC. 1997. Mapa Geomorfológico do Estado de São Paulo, escala 1:500.000. Volume 1. São Paulo: Universidade de São Paulo.

SCHIECK J. 1997. Biased detection of bird vocalizations affects comparisons of bird abundance among forested habitats. Condor 99: 179-190. 
SHERMAN PT AND EASON PK. 1998. Size determinants in territories with inflexible boundaries: manipulation experiments on White-winged Trumpeters' territories. Ecology 79: 1147-1159.

SICK H. 1997. Ornitologia Brasileira. Rio de Janeiro: Editora Nova Fronteira.

SliwA A AND Sherry TW. 1992. Surveying wintering warbler populations in Jamaica: point counts with and without broadcast vocalizations. Condor 94: 924-936.

Stotz DF, FitzPATrick JM, PARKER III TA AND MosKoviTs DK. 1996. Neotropical birds. Ecology and conservation. Chicago: University of Chicago Press.

SWIFT BL, ORMAN SR AND OZARD JW. 1988. Response of Least Bitterns to tape-recorded calls. Wilson Bull 100: 496-499.

ThOMPSON WL. 2002. Towards reliable bird surveys: accounting for individuals present but not detected. Auk 119: 18-25.
Uezu A, Metzger JP ANd Vielliard JME. 2005. Effects of structural and functional connectivity and patch size on the abundance of seven Atlantic Forest bird species. Biol Conserv 123: 507-519.

Veloso HP, RANGel Filho ALR AND Lima JCA. 1991. Classificação da vegetação brasileira adaptada a um sistema universal. Rio de Janeiro: IBGE.

VIELliaRd J AND SILVA WR. 1990. Nova metodologia de levantamento quantitativo da avifauna e primeiros resultados do interior do Estado de São Paulo, Brasil. In: IV ENCONTRO NACIONAL DE ANILHADORES DE AVES, Recife. Universidade Federal Rural de Pernambuco, PE, Brasil, p. 117-151.

WILLIS EO. 1979. The composition of avian communities in three remanescent woodlots in southern Brazil. Papéis Avuls Zool 33: 1-25.

ZAR JH. 1999. Biostatistical analysis. Upper Saddle River, New Jersey: Prentice Hall International Editions. 